\title{
LETTERS TO THE EDITOR
}

\author{
frOM HANS KELLER
}

IT is decades since I last availed mysclf of the right to reply to a review appealing, and indeed playing, to my reputation amongst those who have never read me, heard me, or been taught by me. At an international festival the other month, I told my lecture audience that $I$ had counted eleven pupils amongst the festival's artists (composers and performers), and that it was merely due to the incidental circumstances of my teaching activities that the infantile insults to which my work had been subjected in the past had altogether ceased. Corrigendum: they haven't.

Throughout his review of Stravinsky Seen and Heard, Malcolm Hayes cites me quite inaccurately, to the point of distortion, fantasy, and downright invention. At the same time, his long review does not contain a single specifically musical remark-anything that could not easily have been written by a non-musician. Above all, however, I beg any genuinely interested reader not to think that what Malcolm Hayes says I said in TEMPo $14 \mathrm{I}$ is anywhere near what I said.

My hypotheses are based on factual submissions-on musical facts about which all musicians (Stravinsky included) agree. Significantly enough, for instance, Mr Hayes reports that Stravinsky 'endorsed' my analysis of In Memoriam Dylan Thomas (he did a bit more than that), but not the fact that equally, Stravinsky privately agreed, without reservation, with my analytic diagnosis that his serial technique was emphatically Schoenbergian, not Webernian: 'Mr Keller is absolutely right', he wrote--unlike Mr Hayes who, instead, turns my diagnosis into the product of 'an attitude of mind' which prevents us from gaining 'genuine insight into the later Stravinsky, or anyone else for that matter.'

For the rest, had I said w'at Mr. Hayes says I said, a composer-revie:ver could hardly have come to the conclusion, in one of your sister journals, that 'anyone who professes to care about the state of tiventieth-century music should possess this stimulating, valuable, and utterly unique book', while Carl Dahlhaus, whose own comprehensive summary of my argument (which he accepts in toto) is wholly accurate, could not have drawn attention to the strictly misical evidence-the recordings of Webern's own interpretations of his music-for my characterization of the composer's creative personality. 'In the Stravinsky year', he adds, 'we have to expect a lot of superfluous an'l boring literature. Hans Keller's essay is the opposite: a challenge, supportcd by irresistable argumentation'.

I am not merely juxtaposing unfavourable and favourable reviews: the value of $\mathrm{Mi}$ Hayes' roview is not a matter of opinion or taste. He is either right or wrong, and if he is right, Messis Dahlhaus and Co. are wrong. What is a matter of opinion is the question whether 'Hans Keller has now enshrined himself as the pundit that we all love to hate.' We all? Mr Hayes will have to sneer for himself, unless he can accept my challenge to find me the recognized composers and performers who agree with him; Stravinsky, for one, did not. If, on the other hand, the first person plural is intended to exclude musicians, this qualification ought to have been articulated in 'a quarterly review of modern music'.

London N.IW.3

\section{from MICHAEL STEWART}

1 was interested to rearl Philip Grange's review in TEMPo 140 of the production by York University Music Department of three contemporary music-theatre pieces. Without wishing to detract from the enterprise and originality of the presentation, can I mention that Kagel's Pas de Cing was not in fact the British première: this was given by Focus Opera Group in May 1969 at the Round House, London, as part of an 'Open Forum' on Contemporary Music Theatre. Pas de Cinq was directed by Michael Graubart and myself, the five performers being Michael Jon Kinsman, John Mitchell, Jamie Muir, Howard Skempton, and Robin Thompson. The speakers in the Open Forum which followed incluted Harrison Birtwistle, Hans Keller, and Tim Souster. 


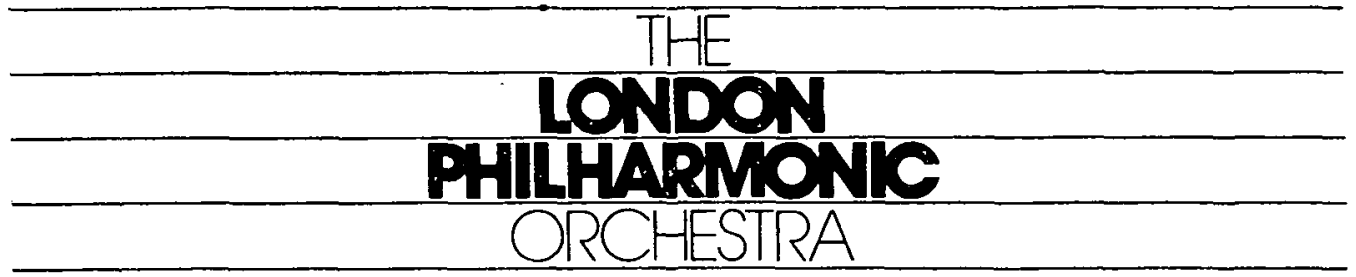

\title{
FIFTIETH ANNIVERSARY SEASON 1982-83
}

\author{
20th-CENTURY MUSIC
}

at the

\section{ROYAL FESTIVAL HALL}

BARTCK

Dance Suite

Piano Concerto 2

14 Dec Solti

30 Oct Fischer/

Ashkenazy

\section{BERKELEY}

Flute Concerto

10 Dec Pritchard!

Galway

\section{DEBUSSY}

Jeux

La Mer

23 Jan Haitink

10 Dec Pritchard

DELIUS

Brigg Fair

7 Oct Solti

\section{FALLA}

N!ghts in the Gardens 25 Nov Chailly/ of Spain

\section{MAHLER}

Symphony 5

Symphony 6
26 Jan Haitink

3I Mar Tennstedt

\section{MCCABE}

Concerto for Orchestra 10 Feb Solti

(LPO commission. World première)

\section{PREVIN}

Reflections

(British première)

11 Oet Previn

\section{PROKOFIEY}

Scherzo \& March. 'The 25 Nov Chailly Love of Three Oranges'

Piano Concerto 125 Nov Chailly/ Orozes

\section{STRAUSS}

Alpine Symphony $15 / 17$ Oct Previn

Four Last Songs $28 \mathrm{Mar}$ Tennstedt/ Popp

\section{STRAVINSKY}

Suite, 'The Firebird' 30 Oct Fischer

Jeu de Cartes 30 Oct Fischer

\section{VAUGHAN WILLIAMS}

Tallis Fantasia

18 Apr Lopez-Cobos

Tickets from Royal Festival Hall Box Office (01-928 3191) and agents from one month in advance of each concert

THE LPO FIFTIETH ANNIVERSARY YEAR BOOK is packed with fascinating features about the Orchestra's history, present activities and future plans. Superbly produced with 130 photographs, it includes a guide to LPO records and comes with a handy pocket-size booklet giving full details of all tha Orchestra's appearances in its Golden Jubilee season. Obtainabie at Royal Festival Hall Music Shop or at LPO, 53 Welbeck Street, London WIM 7HE, price $£ 2.50$ ( $\$ 3.00$ by post). 

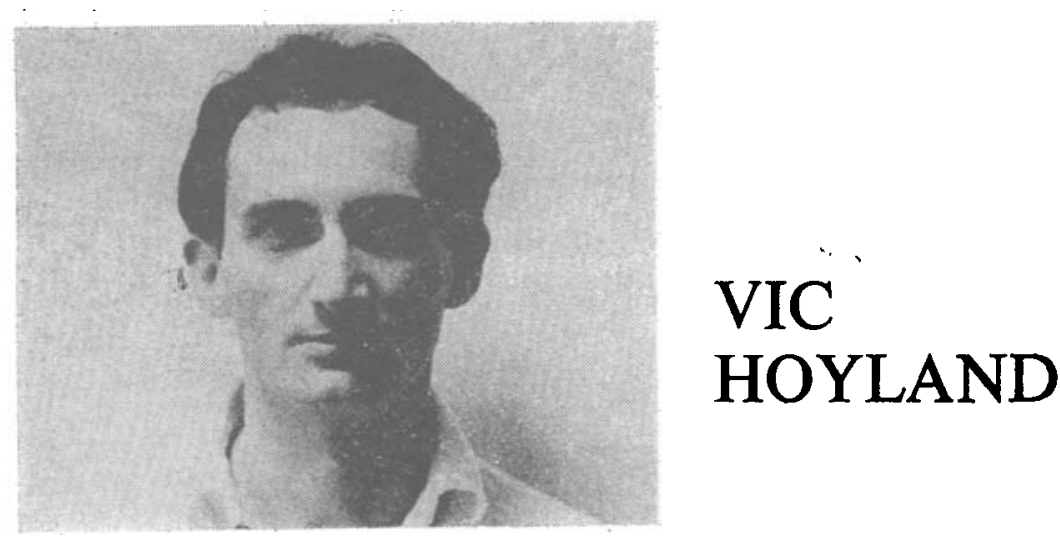

Published score:

JEUX-THEME for mezzo-soprano and chamber ensemble

Dyeline scores:

XINGU music theatre work for orchestra and children

SERENADE for 14 players

(LE) ESEM for double bass and instruments

ANDACHT ZUM KLEINEN for 9 players

(E) REEL for double reed instruments

ARIEL for voice, solo flute and instruments

(LE ES for voices and instruments

EM for 24 voices

Prices on application

UE Please write for brochure on this composer 